\title{
Aerobik Ardışık Kesikli Reaktörde Nitrifikasyon İnhibisyonunun Reaktör Performansı ve Çıkış Suyu Kalitesi Üzerine Etkisi
}

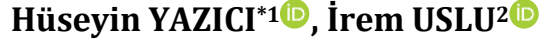 \\ ${ }^{1}$ Isparta Uygulamalı Bilimler Üniversitesi, Aksu Mehmet Süreyya Demiraslan Meslek Yüksekokulu, Çevre Koruma \\ Teknolojileri Bölümü, 32510, Isparta, Türkiye \\ ${ }^{2}$ Süleyman Demirel Üniversitesi, Mühendislik Fakültesi, Çevre Mühendisliği Bölümü, 32260, Isparta, Türkiye
}

(Alınış / Received: 16.01.2020, Kabul / Accepted: 05.05.2020, Online Yayınlanma / Published Online: 20.08.2020)

Anahtar Kelimeler

Ardışık kesikli reaktör, Aktif çamur,

Nitrifikasyon,

İnhibisyon,

Çıkış suyu kalitesi
Özet: $\mathrm{Bu}$ çalışmada aerobik ortam şartında işletilen laboratuvar ölçekli bir ardışık kesikli reaktörde (AKR) uygulanan nitrifikasyon inhibisyonunun reaktör performansina ve çıkış suyu kalitesine etkisi incelenmiştir. Bașlangıç kimyasal oksijen ihtiyacı (KOİ) konsantrasyonunun reaktör işletiminin 42. gününe kadar $250 \mathrm{mg} / \mathrm{L}$ ve sonrasında $500 \mathrm{mg} / \mathrm{L}$ olarak ayarlandığı sentetik atıksuyun beslendiği reaktörde 52 gün boyunca reaktörden çamur çekilmeden ve reaktördeki $\mathrm{pH}$ ayarlanmadan işletme yapılmıștır. Reaktör işletiminde ilk 42 günlük periyodun sonunda KOİ giderim verimi \%93 ve çamur hacim indeksi (ÇHI) değeri $35,0 \mathrm{~mL} / \mathrm{g}$ olarak hesaplanmıștır. Başlangıç KOİ konsantrasyonunun $500 \mathrm{mg} / \mathrm{L}$ değerine artırılması ile birlikte reaktörde döngü sonlarında ölçülen $\mathrm{pH}$ değerlerinde ani bir düşüş yaşanmıştır. Bunun sonucunda arıtma veriminin ve reaktör performansının azalması nedeni ile reaktör işletimi 52. günde sonlandırılmıştır. Çıkış suyunun amonyum $\left(\mathrm{NH}_{4}{ }^{+}\right)$, nitrit $\left(\mathrm{NO}_{2}^{-}\right)$ve nitrat $\left(\mathrm{NO}_{3}^{-}\right)$konsantrasyonlarına ait sonuçlar AKR sisteminin çıkış sularından nütrient geri kazanım potansiyelini artırmak üzere nitrifikasyon inhibisyonunun alternatif bir yaklaşım olarak potansiyelinin bulunduğunu ortaya koymuştur.

\section{The Effect of Nitrification Inhibition on Reactor Performance and Effluent Quality in an Aerobic Sequencing Batch Reactor}

\section{Keywords}

Sequencing batch reactor, Activated sludge, Nitrification, Inhibition, Effluent quality

\begin{abstract}
In this study, the effect of the nitrification inhibition applied in a labscale aerobic sequencing batch reactor (SBR) on the reactor performance and effluent quality was investigated. Reactor operation was carried out during 52 days without wasting any reactor sludge and adjusting $\mathrm{pH}$ in the reactor, where a synthetic wastewater solution with an initial chemical oxygen demand (COD) concentration of $250 \mathrm{mg} / \mathrm{L}$ until the $42^{\text {nd }}$ day of reactor operation and then adjusted to $500 \mathrm{mg} / \mathrm{L}$ was fed. According to the results, COD removal efficiency and sludge volume index (SVI) value was calculated as $93 \%$ and $35.0 \mathrm{~mL} / \mathrm{g}$, respectively, at the end of the day $42^{\text {nd }}$ of the reactor operation. As the initial COD concentration was increased to $500 \mathrm{mg} / \mathrm{L}$, there was a sudden drop in $\mathrm{pH}$ values measured at the end of each cycle in the reactor. As a result of this, the reactor operation was terminated on the day $52^{\text {nd }}$ due to the decrease in the treatment efficiency and the reactor performance. The obtained results of ammonium $\left(\mathrm{NH}_{4}{ }^{+}\right)$, nitrite $\left(\mathrm{NO}_{2}^{-}\right)$and nitrate $\left(\mathrm{NO}_{3}^{-}\right)$concentration in the effluent of the SBR system showed that nitrification inhibition had a potential as an alternative approach to increase the potential of nutrient recovery.
\end{abstract}




\section{Giriş}

Atık akımlarında mevcut bulunan nütrientler ağırlıklı olarak karbon (C), azot (N) ve fosfor (P) bileșikleridir. Her üçü de çeşitli yaşam formlarının temel dayanağı olmaları bakımından önemlidir. $\mathrm{N}$ ve $\mathrm{P}$ hücredeki DNA'nın, aminoasitlerin ve klorofillerin önemli bileşenleridir. $P$ ökaryotik hücrelerde adenozin trifosfat (ATP) formunda bulunarak hücrelerin enerji sirkülasyonu üzerinde önemli rol oynar [1]. $\mathrm{N}$ ise küresel N döngüsü yoluyla bitki gelişiminde ve besin kaynağı sağlanmasında önemli roller oynayarak canlılar için gerekli olan besinin sağlanması işinde rol oynar [2].

Birçok atıksu yüksek miktarda nütrientleri içermektedir ve bu nütrientler sucul ortamda yaşayan mikroorganizmaların gelişimini ve aynı zamanda suların çözünmüş oksijen ihtiyacını da artırmaktadır. Atıksuların doğru arıtma yöntemleri uygulanmadan deşarj edildiği alıcı ortamlarda zamanla septik şartlar meydana gelirken atıksuların içerisinde bulunan çözünmüş ya da askıda organik maddelerin parçalanması sonucunda da kötü koku oluşmaktadır. [3].

Nütrientlerin yüzeysel sulara deşarjı ile oluşan tehlikelere karşı artan toplumsal farkındalık $\mathrm{N}$ ve P'nin atıksulardan gideriminin sağlanması veya iyileştirilmesi için yerel yönetimler üzerinde baskı oluşturmaktadır. Nütrient giderimi konusunda şu anki amaç nütrientlerin giderimini en hafif sosyal ve çevresel etkiye sebep olacak şekilde en düşük maliyetle tamamlamaktır. $\mathrm{Bu}$ üç alanda (sosyal, çevresel ve ekonomik etki) meydana gelecek olumsuz durumları hafifletmek, yerel yönetimlere atıksu arıtımında sürdürülebilirlik yaklaşımı sergilemeyi sağlar. Son 20 yılda tüm dünyada araștırmacılar ve uygulayıcılar konvansiyonel prosesler üzerinde birçok iyileştirme yapmıştır ve mevcut arıtma seviyesinin üstüne çıkan ve düşük işletme maliyeti potansiyeli olan birçok yeni teknoloji geliştirmiştir. Bu prosesler enerji ihtiyacını önemli düzeyde azaltan $\mathrm{N}$ giderimini ve atıksudan enerji üretimini sağlayan proseslerin yanı sıra suyun ve nütrientlerin geri kazanımını ve tekrar kullanımını sağlayan prosesleri içermektedir [4].

Kanada'daki atıksu arıtma tesislerinin arıtma seviyesinin oldukça çeşitli olduğu ve her bölge için farklı nütrient deşarj mevzuatlarına ve değişken seviyelerde alıcı su ortamı hassasiyetine sebep olduğu tespit edilmiştir [4]. Amerika Birleşik Devletleri'ndeki tesislerin birçoğunun ise yalnızca organik madde giderimi yaptığı ve $N$ ve $P$ gibi nütrientlerin giderimi hususundaki artan baskıların optimizasyon ve kontrol teşkil eden karmaşı prosesler gerektirdiği belirtilmiştir [5]. Anlaşıldığ üzere nütrientlerin sosyal, çevresel ve ekonomik anlamda en hafif etkilere sebep olacak şekilde atıksulardan giderimini sağlayabilecek teknolojiler bulunmasına rağmen arıtma tesisleri açısından deșarj standartlarının farklılık göstermesinin en önemli nedenlerinin başında yasal mevzuatların bağlayıcılık durumu gelmektedir.

Evsel atıksuların arıtılması ile ilgili olarak ülkemizdeki durum ise Türkiye İstatistik Kurumu (TÜIK) tarafından yayımlanan Belediye Atıksu Göstergelerinde belirtilen rakamlar ile açıklanabilir [6]. Buna göre geçmiş 20 yılda ülkemizde hem arıtma tesislerinde arıtılan atıksu miktarının hem de ileri arıtma sistemlerinde arıtılan atıksu miktarının arttığ görülmüştür. $\mathrm{Bu}$ gelişmelerle birlikte geçmiş 20 yıldan bu yana hiç arıtılmadan alıcı ortama deşarj edilen veya arıtılan atıksuların ileri arıtma tesisleri haricindeki tesislerden alıcı ortama deşarj edilen miktarlarından dolayı özellikle $\mathrm{N}$ ve $\mathrm{P}$ kaynaklı kirliliğin alıcı ortamlarda meydana getirdiği ekolojik problemler de ayrıca göz önüne alınabilir.

Ülkemizde evsel nitelikli atıksuların arıtılması ile ilgili deşarj standartlarının yer aldığı mevzuatlar [7-10] incelendiğinde ise arıtma tesislerinden yapılacak deşarjlarda alıcı ortamın ötrofikasyon yönünden hassas olup olmadığı değerlendirilmekle birlikte hassas olmayan alanlar kapsamına giren alıcı ortamlara yapılacak deşarjlar için arıtma tesislerinin $\mathrm{N}$ ve $\mathrm{P}$ giderimi açısından herhangi bir standarda tabi olmadığı anlaşılmaktadır. Hassas alanlara deşarj yapan tesisler için ise $\mathrm{N}$ ve $\mathrm{P}$ giderimi açısından kısıtlayıcı hükümlerin bulunduğu anlaşılmaktadır. Bu kapsamda mevcut tesis tasarımları ile $\mathrm{N}$ ve $\mathrm{P}$ giderimi açısından deşarj standartlarını sağlamakla meşgul olan tesislerde çıkış suyunun bu parametreler açısından nasıl daha kaliteli hale getirilmesi gerektiği hususu ön plana çıkmaktadır.

Tüm dünya genelinde su kalitesi mevzuatları alıcı su ortamlarındaki ötrofikasyon problemlerinin üstesinden gelmek üzere nütrient giderimi ile ilgili standartları artırmıştır [11]. Nütrientlerin çevreye deşarjını kısıtlamak üzere artan yasal baskılar hem çıkış suyu deşarjları hem de arıtma çamurlarının arazi uygulamaları açısından izin verilebilir limitlerin daha da sıkılaşmasına yol açmıştır. Bu durum nihayetinde özellikle kısıtlı P kaynaklarının korunması gerektiği hususundaki ihtiyaç için farkındalık artışı ile birlikte birçok ülkenin nütrient geri kazanımı konusuna karşı ilgisinde artışa sebep olmuştur [12]. Nüfus artışı, azalan doğal kaynaklar ve iklim değișikliği konuları atıksu arıtımı endüstrisinde bir paradigma değişimine gitmeyi gerektirmiş̦tir. $\mathrm{Bu}$ gereksinimler özellikle arıtma tesisi çamurlarının yalnızca bertaraf edilmesi gereken bir atık olarak değil, önemli bir kaynak olarak düşünülmesini sağlamaktadır. Nütrient geri kazanımı şu an kaynakların geri kazanımı açısından düşük maliyetli ve çevre açısından sürdürülebilir stratejilerden biri olarak araştırılmaktadır [13].

Bu çalışmaya konu olan ilgili literatürün incelenmesi sonucunda nütrient geri kazanımı çalışmaları açısından temel yaklaşımın ağırlıklı olarak nütrient 
gideriminin yapıldığı tesislerde çamurdan (biyokütleden) geri kazanım ya da arıtılmamış atıksulardan kaynağında geri kazanım şeklinde olduğu ve çalışmaların ağırlıklı olarak yalnızca P geri kazanımı üzerine yoğunlaştığı gözlenmiştir. Ancak nütrient gideriminin yapılmadığı karbon giderimi üzerine odaklanmış proseslerin çıkış sularından nütrient geri kazanımını temsil edecek çalışmaların yok denecek kadar az sayıda olduğu gözlenmiştir. Bu tespitlerden hareketle çalışmada nütrient gideriminin yapılmadığı bir evsel atıksu arıtma tesisinin çıkış sularından $\mathrm{P}$ ile birlikte $\mathrm{N}$ geri kazanım potansiyeli laboratuvar ölçekli ardıșık kesikli reaktör (AKR) sisteminde araştırılmıştır. Öte yandan çıkış sularında amonyum $\left(\mathrm{NH}_{4}{ }^{+}\right)$konsantrasyonunda artış sağlanması amacı ile karbon giderimi sürecinde gerçekleşen nitrifikasyonun inhibe edilmesinin çıkış sularından nütrient geri kazanımı potansiyeline olan etkisi literatürde yapılan çalışmalarda araştırılmamıştır. $\mathrm{Bu}$ yaklaşım, gerçekleştirilen çalışmanın özgünlüğünü oluşturmaktadır. Çalışma kapsamında aerobik ortam şartında doldur-boşalt şeklinde işletilen laboratuvar ölçekli bir AKR'de nitrifikasyon inhibisyonunun reaktör performansı ve çıkış suyu kalitesi üzerine etkisinin belirlenmesi amaçlanmıștır.

\section{Materyal ve Metot}

$\mathrm{Bu}$ çalışmada reaktör işletimi aşamaları, sentetik atıksu ile beslenen ve aerobik şartlar altında işletilen bir AKR'de nitrifikasyon inhibisyonu uygulanmasının reaktör performansı ve çıkış suyu kalitesi üzerine etkisini incelemek üzere farklı işletme stratejilerini kapsamaktadır. Bu stratejiler, hızlı çökebilen ve arıtma performansı yüksek olan bir aktif çamur elde etmek üzere on beş günlük alıştırma aşaması boyunca beş günlük aşamalar halinde uygulanmıştır. Reaktör işletimi, ilk 15 günü alıştırma aşaması olmak üzere toplam 52 gün yürütülmüştür. Reaktör işletiminin ilk 44 gününde sentetik atıksudaki başlangıç KOİ konsantrasyonu $250 \mathrm{mg} / \mathrm{L}$ ve 44 . günden itibaren $500 \mathrm{mg} / \mathrm{L}$ olarak ayarlanmıştır. Çalışma süresince reaktörde uygulanan işletme stratejilerinin, ÇHİ değerinin ve çıkış suyunun askıda katı madde (AKM) ve KOİ konsantrasyonunun oldukça düşük olmasına sebep olacağı tahmin edildiğinden biyokütlenin mümkün olduğu kadar reaktörde alıkonması (yüksek çamur yaşı (SRT) şartlarında işletim) hedeflenmiştir. Bu nedenle tüm işletme süresi boyunca döngü sonlarında reaktörden çamur atılmadan işletme yapılmıştır. Ayrıca döngü başlarında karışık sıvıda başlangıç pH değeri ayarlanmamıştır.

\subsection{Reaktör işletimi}

Reaktör işletiminde kullanılan aşı çamuru Antalya Lara İleri Atıksu Arıtma Tesisi'nin havalandırma havuzundan temin edilmiştir. Tüm deneysel çalışmalar boyunca 5,0 L çalışma hacmine sahip aerobik modda işletilen bir AKR kullanılmıştır.
Reaktörün 15 günlük alıştırma aşamasında ve sonrasındaki işletme aşamasında döngü süreleri, sentetik atıksu hacmi ve hesaplanan hidrolik bekleme süreleri (HRT) Çizelge 1'de görülmektedir. Alıștırma aşaması boyunca ve sonrasındaki işletme aşaması boyunca günde 12 saatlik bir döngü uzun döngü olarak sabit şekilde uygulanmıştır. Alıștırma aşamasının altıncı gününden itibaren diğer 12 saatlik döngü ise beş gün boyunca günde 6 saatlik iki döngü halinde ve on birinci günden itibaren beş gün boyunca günde 4 saatlik üç döngü halinde kısa döngü olarak uygulanmıştır. Reaktöre sentetik atıksu beslemesi alıştırma aşamasının ilk 5 gününde 2,5 L/döngü ve 6. günden itibaren tüm işletme aşamaları boyunca $3 \mathrm{~L} /$ döngü hacminde yapılmıştır. Alıștırma aşaması boyunca kademeli olarak hem döngü sürelerinin kısaltılması ile hem de sentetik atıksu hacminin artırılması ile HRT kısaltılarak aktif çamurun çökme performansının iyileştirilmesi hedeflenmiştir. Her bir döngüyü oluşturan aşamalar Çizelge 1'de görülmektedir. Tüm reaktör işletimi boyunca doldurma işlemi, havalandırma işleminin ilk 10 dakikası boyunca havalandırma başlatıldığı anda reaktörde karıştırma yapılmadan yürütülmüştür. Alıştırma aşamasında aktif çamurun çöktürülmesi işlemi 1. günde $19 \mathrm{dk}$. olmak üzere ilk 10 gün boyunca birer dakikalık azalmalarla 10. gün sonunda $10 \mathrm{dk}$. olacak şekilde yürütülmüştür. Devam eden günlerde çöktürme süresi reaktör işletimi sonlandırılana kadar $10 \mathrm{dk}$. olarak uygulanmıştır. Havalandırma işlemi ise alıştırma aşamasında çöktürme süresinin ilk 5 günde birer dakika kısaltılmasına bağlı olarak 691-695 dk., 6-10 günlük aşamada 12 saatlik döngülerde $696-700 \mathrm{dk}$ ve 6 saatlik döngülerde $336-340 \mathrm{dk}$ ve sonraki tüm işletme aşaması boyunca reaktör işletimi sonlandırılana kadar 12 saatlik döngülerde $700 \mathrm{dk}$. ve 4 saatlik döngülerde $220 \mathrm{dk}$ olacak şekilde uygulanmıştır. Döngü sonlarında çıkış suyu olarak reaktörden boşaltılan hacmin yerine her döngünün başlangıcında taze sentetik atıksu reaktöre eklenmiştir. Sentetik atıksuyun ve arıtılan çıkış suyunun doldurma-boşaltma işlemleri için bir adet çift yönlü olarak (saat yönünde ve saat yönünün tersine) ve bir adet tek yönlü çalışan peristaltik pompa kullanılmıştır. Aerobik aşamalar boyunca karıștırma işlemi, reaktörün tabanından bir manyetik karıştırıcı vasıtası ile 900 devir/dk sabit hızda yürütülmüştür. Aerobik aşamalar boyunca havalandırma işlemi, reaktörün taban çevresini dolaşan çubuk şekilli esneyebilir bir akvaryum difüzörü yardımıyla yapılmıştır. Hava kaynağı olarak hava debisinin ayarlanmasına imkan sağlayan akvaryum havalandırıcısı kullanılmıştır. Reaktöre sağlanan havanın debisi, reaktördeki karışık sıvıda ölçülen çözünmüş oksijen konsantrasyonu $\geq 5 \mathrm{mg} / \mathrm{L}$ seviyesinde olacak şekilde en az $1 \mathrm{~L} / \mathrm{dk}$ debide hava sağlanarak bir hava debimetresi aracılı̆gl ile kontrol edilmiștir. Hava debisinin $1 \mathrm{~L} / \mathrm{dk}$ değerinin altına düştüğü durumlarda veya reaktörün cam yüzeyinde biyofilm gelişmesi durumlarında haftalık olarak difüzör ve iç aksam temizliği yapılmıştır. 
Çizelge 1. Reaktör işletiminde döngü süreleri ve HRT değerleri

\begin{tabular}{ccccc}
\hline & $\mathbf{0 - 5}$ gün & $\begin{array}{c}\text { Alıştırma Aşaması } \\
\mathbf{6 - 1 0} \text { gün }\end{array}$ & $\mathbf{1 1 - 1 5}$ gün & $\begin{array}{c}\text { Alıştırma } \\
\text { Aşaması } \\
\text { Sonrası }\end{array}$ \\
\hline Döngü süresi (saat)/gün & $12+12$ & $12+6+6$ & $12+4+4+4$ & $12+4+4+4$ \\
Döngü aşamaları (süre, dk.) & & & & \\
Havalandırma & $691-695$ & $696-700 / 336-340$ & $700 / 220$ & $700 / 220$ \\
Çöktürme & $19-15$ & $14-10$ & 10 & 10 \\
Boşaltma & 10 & 10 & 10 & 10 \\
Sentetik atıksu hacmi (L/döngü) & 2,5 & 3 & 3 & 3 \\
HRT (saat) & 24 & $20 \mathbf{a}$ & $20^{\mathbf{a}}$ & $20^{\mathbf{a}}$ \\
Ortalama HRT (saat) & 24 & $10^{\mathbf{b}}$ & $6,66^{\mathbf{c}}$ & $6,66^{\mathbf{c}}$ \\
& & 15 & 13,33 & 13,33 \\
\hline
\end{tabular}

a: 6. günden itibaren 12 saatlik döngülere karşıllk gelen HRT;

b: 6-10. günlerde 6 saatlik döngülere karşllık gelen HRT;

c: 11. günden itibaren 4 saatlik döngülere karşıllk gelen HRT

Karışık sıvıdaki çözünmüş oksijen konsantrasyonu reaktör temizliğinden önce ve sonra Milwaukee MW600 marka oksijen metre yardımıyla ölçülmüştür. Tüm reaktör işletiminde $\mathrm{pH}$ ölçümleri Milwaukee Mi150 model pH metre ile yapılmıștır. Başlangıç KOİ konsantrasyonunun 500 ve $750 \mathrm{mg} / \mathrm{L}$ olduğu deneysel aşamadaki çalışmalar boyunca reaktöre sentetik atıksu beslemesi yapıldıktan sonra her döngü başında karışık sıvıda ölçülen $\mathrm{pH}$ değerinin $<7,0$ olarak ölçüldüğü her durumda $1 \mathrm{~N} \mathrm{NaOH}$ çözeltisi ile $\mathrm{pH}$ ayarlaması yapılarak $\mathrm{pH}$ değerinin 7,0-7,3 aralığında olması sağlanmıștır. Reaktördeki sıcaklık kontrol edilmemiștir fakat aktüel sıcaklık her döngü başında ve sonunda $\mathrm{pH}$ ölçümleri ile birlikte izlenmiştir.

\subsection{Sentetik atıksu}

Her döngüde doldurma aşamasının başlangıcı ile birlikte reaktöre eklenen sentetik atıksuyun bileşimi Çizelge 2'de verilmektedir. Sentetik atıksuyun bileşimini oluşturan bileşiklerin bir kısmının konsantrasyonu tüm deneysel çalışmalar boyunca sabit olarak ayarlanmıştır. Diğer bileşiklerin konsantrasyonu ise çalışmanın amacına veya sentetik atıksu çözeltisi hazırlamadaki yaklaşıma göre değișkenlik göstermiştir.

Sentetik atıksu, bileșimleri birbirinden farklı olan farklı hacimlerdeki A ve B çözeltileri halinde dört döngülük stok çözeltiler halinde hazırlanmıştır. Her döngü başında 0,75 L A çözeltisi, 2 L B çözeltisi ve $0,25 \mathrm{~L} \mathrm{NH}_{4} \mathrm{Cl}$ çözeltisi nihai çözeltiyi oluşturmak üzere sırası ile reaktöre beslenmiştir. Alıştırma aşamasının ilk 5 gününde toplam sentetik atıksu hacmi 2,5 L olduğundan $\mathrm{A}, \mathrm{B}$ ve $\mathrm{NH}_{4} \mathrm{Cl}$ çözeltileri 3 L'lik toplam hacim içerisindeki hacimlerine oranlanarak hazırlanmıştır. B çözeltisi $4 \mathrm{~mL} / \mathrm{L}$ hacimde iz element çözeltisi içermiştir. İz element çözeltisi A ve B çözeltilerinden ayrı 1 L'lik stok bir çözelti halinde hazırlanıp stok B çözeltisinin hazırlanmasından sonra B çözeltisine ilave edilmiştir. İz elementi oluşturan bileşiklerin miktarları Lu vd. [14] tarafından belirtildiği şekilde ayarlanmıştır. Nitrifikasyon inhibisyonunun sağlandığı çalışmalarda sentetik atıksuya dahil edilen aliltiyoüre (ATU, $\mathrm{C}_{4} \mathrm{H}_{8} \mathrm{~N}_{2} \mathrm{~S}$ ) $8 \mathrm{mg} / \mathrm{L}$ [15] konsantrasyonunda $\mathrm{B}$ çözeltisine dahil edilmiştir.

Çizelge 2. Stok sentetik atıksu çözeltisinin bileșimi

\begin{tabular}{|c|}
\hline 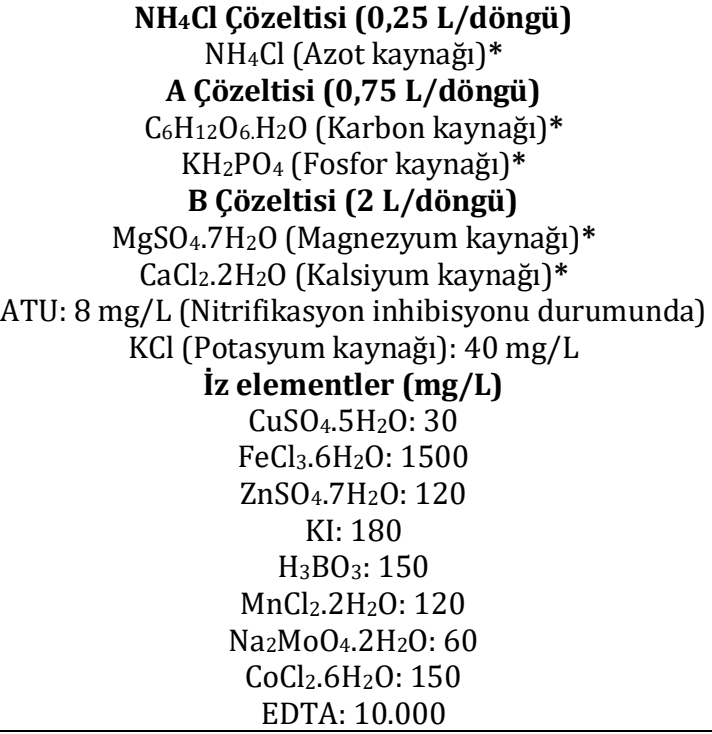 \\
\hline
\end{tabular}

*: Miktarları değişken olan bileşikler

Konsantrasyonları değişken olan bileşiklerin miktarları belirlenirken üç husus göz önüne alınmıştır:

i. Reaktörün farklı organik yükleme hızı (OYH) şartlarında işletilecek olmasından dolayı sentetik atıksudaki başlangıç KOİ konsantrasyonun değişkenlik göstermesi,

ii. Başlangıç KOİ konsantrasyonunun değişmesinden dolayı C/N/P oranına dayalı olarak başlangıç $\mathrm{N}$ ve $\mathrm{P}$ konsantrasyonlarının değişmesi,

iii. Sentetik atıksu kompozisyonunda göz önüne alınması gereken tek değerlikli $\left(\mathrm{NH}^{4+}\right.$ ve $\left.\mathrm{K}^{+}\right)$ve iki değerlikli (magnezyum $\left(\mathrm{Mg}^{2+}\right)$ ve kalsiyum $\left(\mathrm{Ca}^{2+}\right)$ ) katyonlardan ileri gelen toplam tek değerlikli iyon $(\Sigma \mathrm{M})$ konsantrasyonu (meq/L) ve toplam iki değerlikli iyon $(\Sigma \mathrm{D})$ konsantrasyonu (meq/L) arasındaki konsantrasyon dengesi ve $\mathrm{Mg}^{2+}$ ve $\mathrm{Ca}^{2+}$ iyonlarının kendi arasındaki konsantrasyon dengesi. 
Çizelge 3. Sentetik atıksu bileșiminde miktarları değișken olan bileșiklerin miktarları

\begin{tabular}{|c|c|c|c|c|c|c|}
\hline \multicolumn{5}{|c|}{ Bilessik } & \multirow{2}{*}{ OYH } & \multirow{2}{*}{$\Sigma M^{(*)}: \Sigma D$} \\
\hline $\mathrm{C}_{6} \mathrm{H}_{12} \mathrm{O}_{6} \cdot \mathrm{H}_{2} \mathrm{O}$ & $\mathrm{NH}_{4} \mathrm{Cl}$ & $\mathrm{KH}_{2} \mathrm{PO}_{4}$ & $\mathrm{MgSO}_{4} .7 \mathrm{H}_{2} \mathrm{O}$ & $\mathrm{CaCl}_{2.2 \mathrm{H}_{2} \mathrm{O}}$ & & \\
\hline $\begin{array}{c}258 \mathrm{mg} / \mathrm{L} \\
\text { (KOİ: } 250 \mathrm{mg} / \mathrm{L}) \\
\text { (C: } 93 \mathrm{mg} / \mathrm{L})\end{array}$ & $\begin{array}{c}35,5 \mathrm{mg} / \mathrm{L} \\
(\mathrm{N}: 9,3 \mathrm{mg} / \mathrm{L}) \\
\left(\mathrm{NH}_{4}{ }^{+}: 12,0 \mathrm{mg} / \mathrm{L}\right) \\
\left(\mathrm{NH}_{4}+: 0,66 \mathrm{meq} / \mathrm{L}\right)\end{array}$ & $\begin{array}{c}20,4 \mathrm{mg} / \mathrm{L} \\
(\mathrm{P}: 4,65 \mathrm{mg} / \mathrm{L}) \\
\left(\mathrm{PO}_{4}^{3-:}: 14,3 \mathrm{mg} / \mathrm{L}\right) \\
\left(\mathrm{K}^{+}: 0,150 \mathrm{meq} / \mathrm{L}\right)\end{array}$ & $\begin{array}{c}55,4 \mathrm{mg} / \mathrm{L} \\
\left(\mathrm{Mg}^{2+}: 0,45\right. \\
\text { meq/L) }\end{array}$ & $\begin{array}{c}33,0 \mathrm{mg} / \mathrm{L} \\
\left(\mathrm{Ca}^{2+}: 0,45\right. \\
\text { meq/L) }\end{array}$ & $\begin{array}{c}0,25 \text { (a) } \\
0,45 \text { (b) } \\
0,6 \text { (c) }\end{array}$ & $1,35: 0,9$ \\
\hline
\end{tabular}

(a): Alıștırma aşamasının 1-5. günlerindeki OYH (kg KOI//m³.gün) değeri; (b): Alıştırma aşamasının 6-10. günlerindeki OYH değeri; (c): Alıştırma aşamasının 11-15. günlerindeki OYH değeri.

(*): Sentetik atıksudaki $40 \mathrm{mg} / \mathrm{L} \mathrm{KCl}$ bileșiğinden ileri gelen $\mathrm{K}^{+}$konsantrasyonu 0,536 meq/L olarak hesaplanmaktadır.

Sentetik atıksu bileşimi belirlenirken tüm deneysel çalışmalar boyunca $\mathrm{C} / \mathrm{N} / \mathrm{P}$ konsantrasyonları $100 / 10 / 5$ oranında, $\Sigma \mathrm{M} / \Sigma \mathrm{D}=1,5$ oranında ve $\mathrm{Mg}^{2+} / \mathrm{Ca}^{2+}$ iyonlarının oranı 1:1 olacak şekilde sabit tutulmuştur. Buna göre çalş̧manın farklı aşamalarında miktarları değişkenlik gösteren bileşiklerin miktarları hesaplanarak Çizelge 3'te sunulmuștur.

\section{3. Örnekleme ve analiz prosedürleri}

Tüm analizler hem alıștırma aşamasında hem de sonrasında devam eden işletme aşamasında iki günde bir kez yapılmıştır. Analizlerin yapıldığı günlerde hem 12 saatlik uzun döngülerin hem de 4 ve 6 saatlik kısa döngülerin sonunda örnekleme yapılarak analizler yapılmıştır. Örnekler herhangi bir döngünün sonunda toplam örnek hacmi $25 \mathrm{~mL}$ olacak şekilde reaktör tam karışım halindeyken alınmıştır. Analizler, ilgili analiz prosedürünün gerektirdiği şekilde karışık sıvı örneklerinden direkt olarak veya karışık sıvının filtrelenmesi ile elde edilen filtrat örnekleri üzerinden yürütülmüştür. Çamur hacim indeksi (ÇHI) analizlerinde örneklemenin yapıldığı döngünün sonunda reaktör tam karışım halindeyken $1 \mathrm{~L}$ karışık sıvı örneği alınmıştır. Imhoff hunisinde çöktürme işlemi tamamlandıktan sonra çöken çamurun üst kısmında kalan sıvı kısım drene edilmiştir ve kalan çamur yeni döngü başlamadan önce reaktöre tekrar dahil edilmiştir. Böylelikle ÇHI analizi için yapılan örneklemeden ileri gelecek olası biyokütle kaybı önlenmiștir. Örnekler alındıktan hemen sonra bekletilmeden ilgili analiz prosedürü doğrultusunda analizlere tabi tutulmuştur. Karışı sıvı örneklerinde karışık sıvı askıda madde (MLSS), karışık sıvı uçucu askıda katı madde (MLVSS) ve ÇHI analizleri, filtrat örneklerinde ise $\mathrm{KOI}, \mathrm{NH}_{4}{ }^{+}, \mathrm{NO}_{3}{ }^{-}, \mathrm{NO}_{2}{ }^{-}, \mathrm{Ca}^{2+}, \mathrm{Mg}^{2+}$ ve $\mathrm{PO}_{4}{ }^{3-}$ analizleri yapılmıştır.

AKM-MLSS analizleri APHA 2540D yöntemine [16] göre yapılmıştır. Bu prosedürde filtre kağıdı olarak Millipore AP40 ve kurutma işlemi için Nüve FN500 etüv kullanılmıştır. Filtre kağıtlarının daralarının belirlenmesi, kurutma ve yakma ișlemleri sonrasında ağırlıkların belirlenmesi işlemleri Radwag AS220/C12 hassas terazide gerçekleştirilmiştir. MLVSS analizleri APHA 2540E yöntemine [16] göre yapılmıştr. Yakma işlemleri Protherm PLF 110/6 kül fırınında yürütülmüştür. ÇHİ analizleri APHA 2710D yöntemine göre yapılmıștır [16]. Çöken çamur hacmini belirlemek üzere Imhoff hunisi kullanılarak çökebilen katıların volümetrik testi (2540F) uygulanmıştir. Bu metoda göre ham numune Imhoff hunisinin 1 L ölçü çizgisine kadar doldurulduktan sonra 1 saat süre ile çöktürme uygulanmıştır ve süre sonunda çöken çamur hacmi $\mathrm{mL}$ cinsinden huniden okunarak kaydedilmiştir. KOİ ölçümleri APHA 5220D yönteminde [16] belirtildiği şekilde kapalı refluks kolorimetrik yöntemine göre spektrofotometrede (WTW, SpektroFlex 6100 VIS) $600 \mathrm{~nm}$ ve $420 \mathrm{~nm}$ dalga boylarında referans çözeltilere karşı absorbans okuması yapılarak oluşturulan kalibrasyon eğrileri üzerinden yürütülmüştür. KOİ konsantrasyonunun $90 \mathrm{mg} / \mathrm{L}$ değerinden büyük olduğu tahmin edilen örnekler için $600 \mathrm{~nm}$ ve KOİ konsantrasyonunun 90 $\mathrm{mg} / \mathrm{L}$ değerinden küçük olduğu tahmin edilen örnekler için $420 \mathrm{~nm}$ dalga boylarında okuma yapılmıştır. Örnek tüpü içerisine reaktifler ve örnek eklendikten sonra oluşan karışım 2 saat süre ile 150 ${ }^{\circ}$ C'de termoreaktörde (WTW, CR2200) isitılmıştır. Süre sonunda tüpler oda sıcaklığına kadar soğutulduktan sonra spektrofotometrede absorbans değerleri okunmuştur. Elde edilen okuma sonuçları, $600 \mathrm{~nm}$ ve $420 \mathrm{~nm}$ dalga boyları için önceden oluşturulmuş kalibrasyon grafiklerine göre değerlendirilerek örneğin KOİ konsantrasyonu tespit edilmiştir. $\mathrm{PO}_{4}^{3-}, \mathrm{NH}_{4}{ }^{+}, \mathrm{NO}_{2}{ }^{-}, \mathrm{NO}_{3}{ }^{-}, \mathrm{Ca}^{2+}$ ve $\mathrm{Mg}^{2+}$ konsantrasyonlarl spektrofotometrede (WTW SpectroFlex 6100) Merck test kitleri kullanılarak kolorimetrik olarak belirlenmiștir. $\mathrm{Bu}$ amaçla kullanılan test kitleri ve ölçüm aralıkları Çizelge 4'te verilmektedir:

Çizelge 4. Kolorimetrik analizler

\begin{tabular}{ccc} 
Parametre & Prosedür & $\begin{array}{c}\text { Ölçüm Aralığı } \\
(\mathbf{m g} / \mathbf{L})\end{array}$ \\
\hline Amonyum $\left(\mathrm{NH}_{4}{ }^{+}\right)$ & Merck 114752 & $0,01-3$ \\
Fosfat $\left(\mathrm{PO}_{4}^{3-}\right)$ & Merck 114842 & $0,5-30$ \\
Nitrat $\left(\mathrm{NO}_{3}\right)$ & Merck 109713 & $0,10-25$ \\
Nitrit $\left(\mathrm{NO}_{2}^{-}\right)$ & Merck 114776 & $0,002-1$ \\
Kalsiyum $\left(\mathrm{Ca}^{2+}\right)$ & Merck 114815 & $5-160$ \\
Magnezyum $\left(\mathrm{Mg}^{2+}\right)$ & Merck 100815 & $5-75$ \\
\hline
\end{tabular}

\section{Bulgular}

Deneysel çalışmalardan elde edilen sonuçların sunulduğu Şekil 1-7'deki grafik eğrilerinde beyaz dolgu ile gösterilen sonuçlar ilk 15 günlük alıştırma aşamasına aittir.

\subsection{Reaktör performansı}

Reaktör performansı esas olarak aktif çamurun MLSS konsantrasyonundaki değişim, çamurun çökme performansı ve KOİ giderim verimi esas alınarak 
değerlendirilmiştir. Elde edilen sonuçlara göre alıştırma aşamasının ilk 5 gününde ÇHİ $175 \mathrm{~mL} / \mathrm{g}$ değerinden $246 \mathrm{~mL} / \mathrm{g}$ değerine artmiștır. MLSS konsantrasyonu ise çamurun çökme performansında meydana gelen azalma nedeniyle başlangıç değeri olan 2420 mg/L'den 1396 mg/L'ye düşmüştür (Şekil 1). Yaşanan biyokütle kaybı aynı zamanda çıkış suyunun AKM konsantrasyonunun nispeten yüksek olması (75-110 $\mathrm{mg} / \mathrm{L}$ aralı̆̆ında) ile doğrulanabilmektedir (Şekil 2). Alıştırma aşamasının kalan 10 günlük aşamasında ise MLSS konsantrasyonu ve çamur çökme performansı kademeli olarak artış göstermiştir. $\mathrm{Bu}$ aşamanın sonunda (14. günde) MLSS konsantrasyonu 2056 mg/L değerine yükselmiştir ve ÇHİ değeri $131 \mathrm{~mL} / \mathrm{g}$ değerine azalmıştır. Bu durum nihai olarak çıkış suyunun AKM konsantrasyonunun azalmasına (14. günde 16 mg/L) sebep olarak oldukça berrak bir çıkış suyu elde edilmesi ile sonuçlanmıştır.

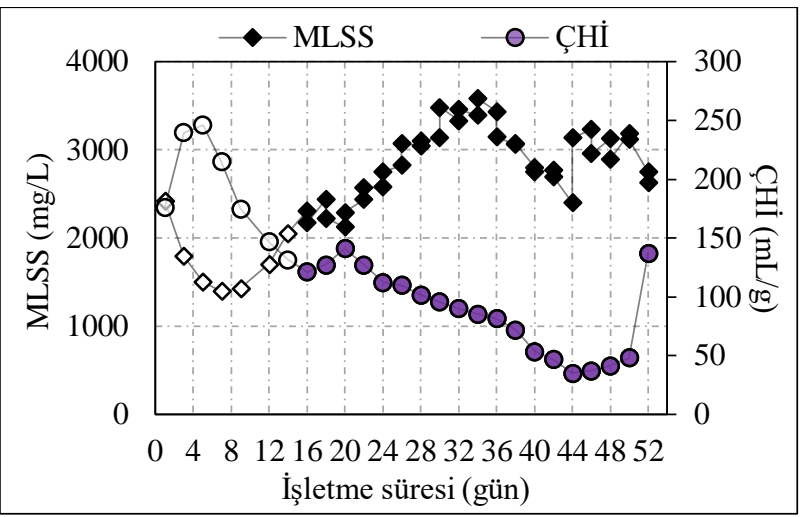

Şekil 1. Reaktörün MLSS ve ÇHİ profilleri.

Alıştırma aşamasından sonraki işletme sürecine ait sonuçlar değerlendirildiğinde ise reaktör işletiminin 36. gününe kadar MLSS konsantrasyonunda kademeli olarak artış (3148 mg/L) ve sonrasında 44. güne kadar azalma $(2400 \mathrm{mg} / \mathrm{L})$ meydana geldiği görülmektedir (Şekil 1). Bu aşamada ÇHİ değeri 44. güne kadar kademeli olarak azalma (44. günde 35 $\mathrm{mL} / \mathrm{g}$ ) göstermesine rağmen 36-44. günler arasında çıkıș suyunun AKM konsantrasyonunda artıș (66-102 $\mathrm{mg} / \mathrm{L}$ aralığında, ortalama 81,5 mg/L) meydana gelmiștir ve dolayısıyla MLSS konsantrasyonu bu aşamada azalmıştır.

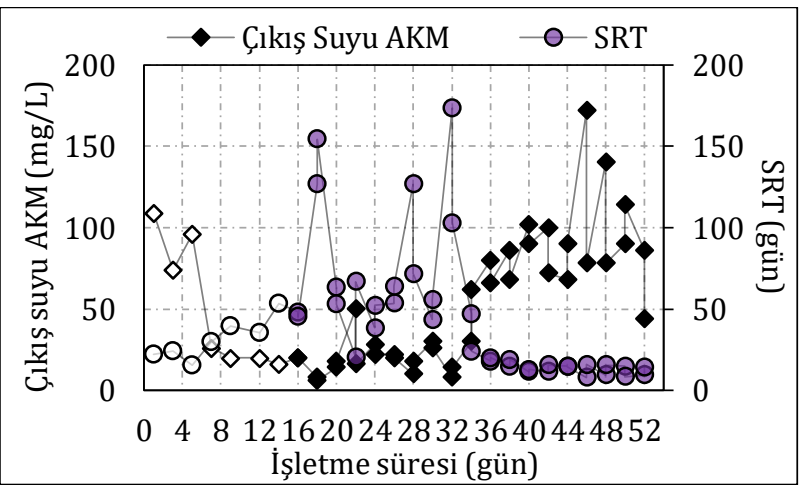

Şekil 2. Reaktörün çıkış suyu AKM ve SRT profili.
Başlangıç KOİ konsantrasyonunun artması ile birlikte MLSS konsantrasyonunda 48. güne kadar bir artış meydana gelmiş fakat bu süreçten sonra reaktördeki işletme şartlarının bozulması nedeni ile 52 . günde reaktör işletimi sonlandırılmıștır. 52 günlük tüm işletme süresi boyunca döngü başlarında karışık sıvının $\mathrm{pH}$ değerinin ayarlanmadan işletme yapılması sebebi ile döngü sonu pH değerleri başlangıç KOİ konsantrasyonunun artırılması ile birlikte önemli ölçüde azalmıştır. Başlangıç KOİ konsantrasyonunun artırıldığı aşamaya kadar tüm ișletme süresince (44. güne kadar) döngü sonlarında ölçülen pH değerleri 6,93-7,83 aralığında değişim gösterirken KOİ konsantrasyonunun artırılmasından sonraki aşamada döngü sonlarında kaydedilen $\mathrm{pH}$ değerleri 4,8-6,0 aralığında değişim göstermiştir (Şekil 3). Karışık sıvı örneklerinin mikroskop altında incelenmesi sonucunda $\mathrm{pH}$ değerinde yaşanan bu ani düşüş ile birlikte filamentli mikroorganizmaların popülasyonunda artış meydana geldiği görülmüştür. Öte yandan çamurun rengi açık sarı renkten orijinal rengi olan koyu kahverengiye değişmiştir.

Reaktörde meydana gelen değişimler neticesinde çamurun çökme performansı azalmıştır. Bu aşamada ÇHI değerinin $35 \mathrm{~mL} / \mathrm{g}$ değerinden $136 \mathrm{~mL} / \mathrm{g}$ değerine kademeli olarak artması (Șekil 1) sonucunda çamurun çökme performansında meydana gelen azalma birlikte çıkış suyunun boşaltılması esnasında yaşanan biyokütle kaybından dolayı MLSS konsantrasyonunda kademeli olarak azalma (52. günde 2628 mg/L) (Şekil 1) ve çıkış suyu AKM konsantrasyonunda kademeli olarak artış (ortalama $99 \mathrm{mg} / \mathrm{L}$, Çizelge 5) meydana gelmiştir (Şekil 2). Reaktördeki işletme şartlarının bozulması neticesinde KOİ giderim verimi de 44-52. günler arasında \%97 değerinden kademeli olarak \%74 değerine azalmıştır (Şekil 3). Reaktör işletimi sonlandırılmadan önce 50-52. günler arasında döngü sonlarında $150 \mathrm{~mL}$ çamur çekilmesine ve döngü başlarında karışık sıvının pH değeri 7,0-7,3 olacak şekilde ayarlanmasına rağmen reaktör şartları iyileştirilememiştir.

Reaktördeki SRT değeri reaktörden çamur atılmadığı için karışık sıvının MLSS konsantrasyonuna ve çıkış suyunun AKM konsantrasyonuna bağlı olarak değişim göstermiştir. İlk 15 günlük alıștırma aşamasında MLSS ve çıkış suyunun AKM konsantrasyonu çamurun çökme performansındaki değişime bağlı olarak dalgalanma yaptığından dolayı SRT değeri önce azalan ve daha sonra artan bir değişim göstermiştir (Şekil 2). Bu aşama için hesaplanan SRT değerleri 15-53 gün aralığındadır ve ortalama olarak 31,5 gün olarak hesaplanmıştır. Alıştırma aşamasından sonraki süreçte karışık sıvının MLSS konsantrasyonunun kademeli olarak arttığı ve çlkış suyunun AKM konsantrasyonunun nispeten daha düşük olduğu 16-36. günler arasında SRT değerleri 20-173 gün aralığında değişim göstermiş ve ortalama olarak 71,6 gün olarak hesaplanmıştır. Bu aşamada SRT değerlerinin nispeten yüksek olması, 
daha önce bahsedildiği gibi flok yapısında sonradan meydana gelen bozulmanın sebebi olduğu düşüncesini desteklemektedir. 36-42. günler arasında flok yapısının bozulması ile birlikte çıkıș suyunun AKM konsantrasyonundaki artışa ve MLSS konsantrasyonundaki azalmaya bağlı olarak SRT değerleri 11,4-19,8 gün aralığında değişim göstermiş ve ortalama olarak 15,2 gün olarak hesaplanmıștır. Başlangıç KOİ konsantrasyonunun artırıldığı 44-52. günler arasında MLSS konsantrasyonu nispeten artmıș olmasına rağmen çamur çökme performansının azalmasından dolayı çıkış suyu AKM konsantrasyonunun artmasına bağlı olarak SRT değerleri bu aşamada 7,8-15,4 gün aralığında değişim göstermiştir ve ortalama olarak 12,2 gün olarak hesaplanmıştır.

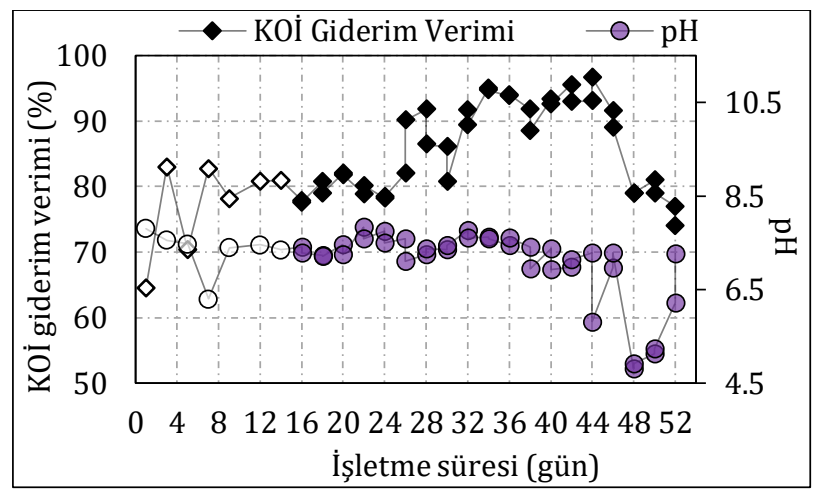

Şekil 3. Reaktörün KOİ giderim verimi ve döngü sonunda ölçülen $\mathrm{pH}$ değerleri.

Reaktörün MLVSS konsantrasyonu ve F/M oranı değişimleri Şekil 4'te görülmektedir. Elde edilen sonuçlara göre MLVSS konsantrasyonundaki değişim karışık sıvının MLSS konsantrasyonunun değişimine orantılı olarak değişim göstermiștir. 52 günlük tüm işletme süresi boyunca MLVSS/MLSS oranı (veri gösterilmemiștir) ortalama olarak \%89 olarak hesaplanmıştır. F/M oranı ise alıştırma aşamasında OYH değerindeki kademeli artışa ve MLSS konsantrasyonundaki değişime bağlı olarak dalgalanma göstermiștir. Hesaplanan ortalama F/M oranları alıştırma aşamasında beşer günlük aşamalar için sırası ile 0,16, 0,35 ve 0,36 kg KOI/kg MLVSS.gün olarak elde edilmiștir. Alıștırma aşamasından sonraki aşamada ortalama $\mathrm{F} / \mathrm{M}$ değerleri ise $\mathrm{OYH}$ değerinin artırıldığı 44. güne kadar 0,24 kg KOI/ $\mathrm{kg}$ MLVSS.gün ve işletmenin sonraki aşaması için ise $0,44 \mathrm{~kg} \mathrm{KOI} / \mathrm{kg}$ MLVSS.gün olarak hesaplanmıştır.

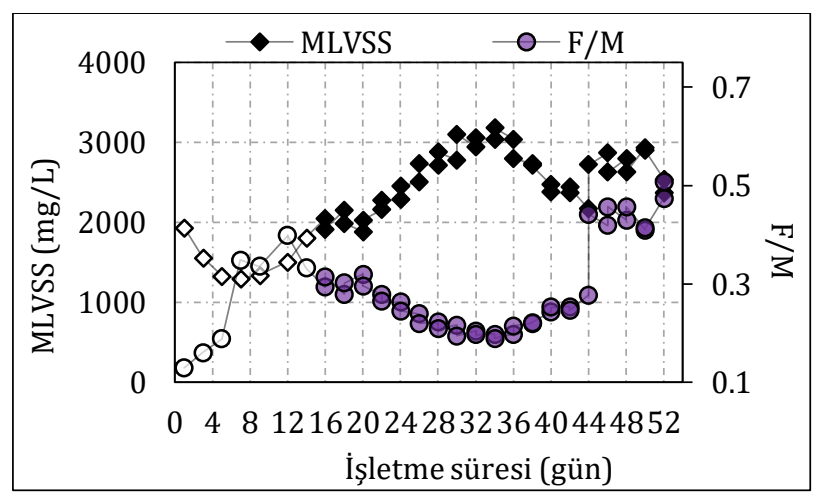

Şekil 4. Reaktörün MLVSS ve F/M profili.

\section{2. Çılkış suyunun $\mathrm{NH}_{4}{ }^{+}$ve $\mathrm{PO}_{4}{ }^{3-}$ profili}

Nitrifikasyonun inhibe edilmesi amacıyla tüm işletme süresi boyunca sentetik atıksuya inhibitör dahil edilerek besleme yapılan reaktörün çıkış suyunun $\mathrm{NH}_{4}{ }^{+}$ve $\mathrm{PO}_{4}{ }^{3-}$ konsantrasyonu ölçümlerinden elde edilen sonuçlar Şekil 5'te görülmektedir. Çıkış suyunun $\mathrm{PO}_{4}^{3-}$ profili incelendiğinde alıștırma aşaması boyunca konsantrasyonların dalgalanma gösterdiği tespit edilmiştir. Alıştırma aşamasından sonra ise konsantrasyonlar 6,4-23,3 mg/L aralığında değişim göstermiştir ve ortalama olarak $11,8 \mathrm{mg} / \mathrm{L}$ (Çizelge 5) olarak hesaplanmıştır. Başlangıç $\mathrm{PO}_{4}^{3-}$ konsantrasyonunun $14,3 \mathrm{mg} / \mathrm{L}$ olduğu göz önüne alındığında bu aşama boyunca reaktörde düşük verimde $\mathrm{PO}_{4}{ }^{3-}$ giderimi gerçekleștiği sonucu ortaya çıkmaktadır. Bu durum aerobik modda işletilen bir reaktör için beklenen bir durumdur. OYH artışının sağlandığ konsantrasyonunun artması $(28,6 \mathrm{mg} / \mathrm{L})$ ile birlikte çıkış suyundaki $\mathrm{PO}_{4}^{3-}$ konsantrasyonları da artış göstermiştir. Reaktör işletiminin son aşamasında konsantrasyonlar ortalama 18,5 mg/L (Çizelge 5) olarak hesaplanmıștır.

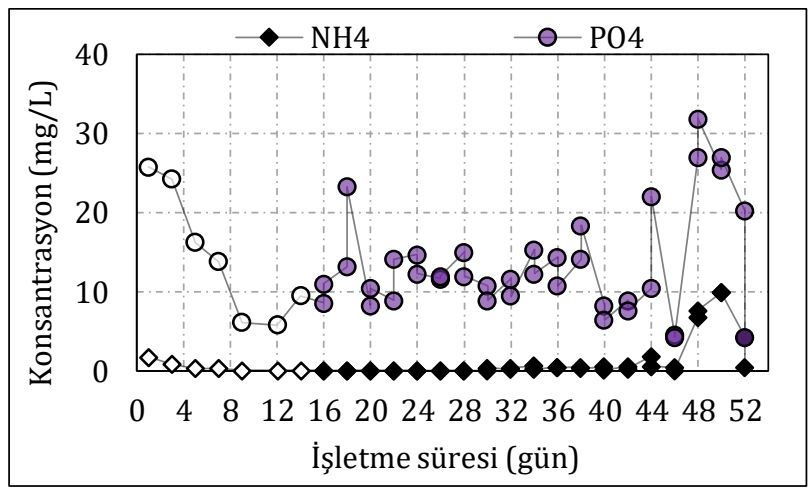

Şekil 5. Reaktörün çıkıș suyunun $\mathrm{NH}_{4}{ }^{+}$ve $\quad \mathrm{PO}_{4}^{3-}$ konsantrasyonu.

Çıkış suyunun $\mathrm{NH}_{4}{ }^{+}$konsantrasyonu ölçümlerinden ve giderilen $\mathrm{NH}_{4}{ }^{+}$konsantrasyonunun hesaplanmasından elde edilen sonuçlara (Şekil 5 ve 6) göre OYH değerinin artırıldığı 44. güne kadar yapılan işletme süresi boyunca çıkış suyundaki konsantrasyonlar 0,05-1,86 mg/L aralığında değişim göstermiştir ve ortalama olarak 0,31 mg/L (Çizelge 5) hesaplanmıştır. OYH artışı ile birlikte başlangıç $\mathrm{NH}_{4}{ }^{+}$ konsantrasyonunun artışına bağlı olarak çıkış suyunun $\mathrm{NH}_{4}{ }^{+}$konsantrasyonu ve giderilen $\mathrm{NH}_{4}{ }^{+}$ konsantrasyonu artış göstermiştir ve 44-52. günler arasındaki aşama için ortalama konsantrasyon 4,46 mg/L değerine yükselmiştir (Çizelge 5).

Reaktörde inhibisyon uygulanmasının etkisi ayrıca çıkış suyunun $\mathrm{NO}_{2}^{-}$ve $\mathrm{NO}_{3}^{-}$konsantrasyonlarının ölçülmesi ile değerlendirilmiştir. Tüm işletme süresi boyunca $\mathrm{NO}_{2}$ - konsantrasyonları ortalama olarak 0,098 $\mathrm{mg} / \mathrm{L}$ olarak hesaplanmıştır (veri gösterilmemiştir). $\mathrm{NO}_{3}-$ konsantrasyonları ise $\mathrm{OYH}$ artışı ile $\mathrm{NH}_{4}{ }^{+}$konsantrasyonunun artmasından 
bağımsız olarak tüm işletme süresi boyunca çok fazla değişim göstermemiştir (Şekil 6) ve ortalama olarak 44. güne kadar 8,41 mg/L ve 44-52. günler arasındaki aşama için 7,87 mg/L olarak hesaplanmıştır (Çizelge 5).

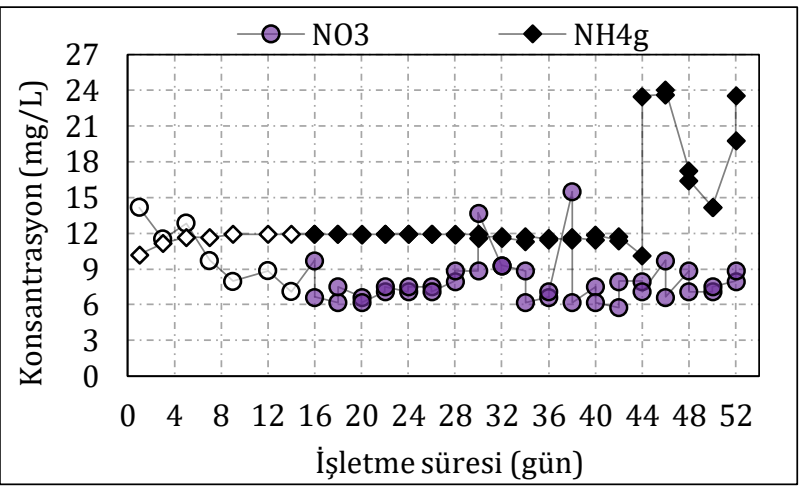

Şekil 6. Reaktörde giderilen $\mathrm{NH}_{4}{ }^{+}\left(\mathrm{NH}_{4 \mathrm{~g}}\right)$ konsantrasyonu ve çlkış suyunun $\mathrm{NO}_{3}{ }^{-}$konsantrasyonu.

İnhibisyonun çıkış suyundaki $\mathrm{NO}_{3}^{-}$ konsantrasyonunun değişimine etkisi ayrıca reaktörde giderilen $\mathrm{NH}_{4}{ }^{+}$konsantrasyonunun çıkış suyundaki $\mathrm{NO}_{3}{ }^{-}$konsantrasyonuna oranı ile değerlendirilmiştir (Şekil 7). Başlangıç $\mathrm{NH}_{4}{ }^{+}$ konsantrasyonunun artırıldığı 44. güne kadar yapılan işletme boyunca ortalama oran 1,36 olarak hesaplanırken 44-52. günler arasında reaktörde giderilen $\mathrm{NH}_{4}{ }^{+}$konsantrasyonunun artmasına ve çıkış suyundaki $\mathrm{NO}_{3}{ }^{-}$konsantrasyonunun inhibisyon etkisi nedeni ile artmamasına bağlı olarak ortalama oran 2,51 değerine yükselmiştir (Çizelge 5).

Tüm işletme süresi üç temel aşamaya (alıştırma aşaması 0-15 gün, başlangıç KOİ konsantrasyonunun artışından önceki aşama 16-43 gün ve başlangıç KOİ konsantrasyonunun artırıldığı aşama 44-52 gün) bölünerek deneysel çalıșmalardan elde edilen sonuçlar ayrıca ortalama değerlere göre Çizelge 5 'te özetlenmektedir.

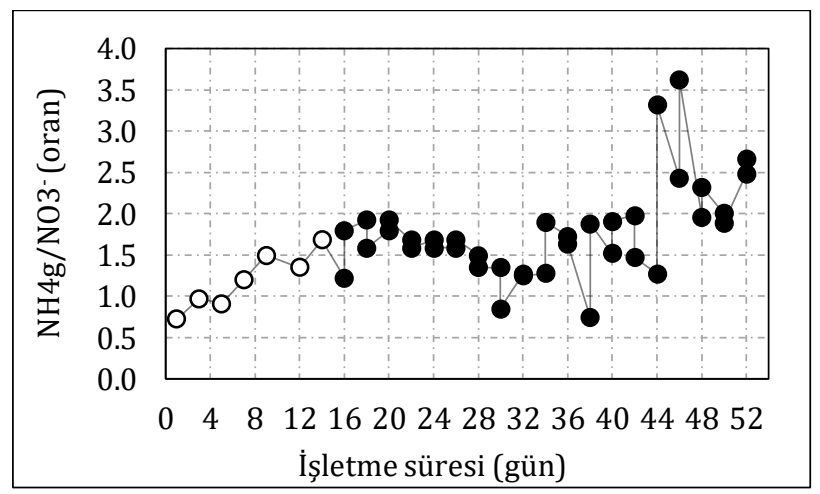

Şekil 7. Giderilen $\mathrm{NH}_{4}{ }^{+}\left(\mathrm{NH}_{4 \mathrm{~g}}\right)$ konsantrasyonunun çıkış suyundaki $\mathrm{NO}_{3}{ }^{-}$konsantrasyonuna oranı.

\section{Tartışma ve Sonuç}

\subsection{Reaktör performansı}

Reaktör işletiminin ilk 5 gününde MLSS konsantrasyonunda meydana gelen azalma; (i) çamurun çökme performansının azalması sebebiyle çamurun bir kısmının çöktürme aşamasının sonunda çıkıș suyunun boşaltıldığı noktanın altına inememesi, ve (ii) flok yapısına henüz dahil olamamıș veya floka zayıf halde bağlı halde olan küçük boyutlu partiküllerin çökmekte zorlanmasından dolayı çıkış suyunda disperse halde bulunması sebebiyle çıkış suyunun boşaltılması esnasında yaşanan biyokütle kaybından ileri gelmiştir.

36-44. günler arasında çamurun çökme performansı hala artıyor olmasına rağmen çıkış suyunun AKM konsantrasyonunun artması (Şekil 2), bu süreçte flok yapısında meydana gelen bir değişimin (muhtemelen granüler flok yapısından tekrar floküler flok yapısına değişim) disperse haldeki partiküllerin miktarında artışa sebep olması ile ilişkilendirilmiştir. Konvansiyonel biyolojik aritma sistemlerine kıyasla daha uzun SRT değerlerine sahip olan şartlarda işletilen membran biyoreaktör (MBR) sistemlerinin yüksek biyokütle konsantrasyonu nedeni ile arıtma veriminde daha fazla artışa imkan sağladığı ve bu avantajından dolayı bazı MBR sistemlerinin sonsuz SRT şartında işletilebildiği belirtmiştir [17]. Sonsuz SRT şartında 4 ay boyunca ișletilen membran AKR sisteminde farklı işletme değişkenlerinin çöp deponi sahası sızıntı sularının arıtılması üzerine etkileri araştırılmıştır [18]. Elde edilen sonuçlar başlangıç değeri $7000 \mathrm{mg} / \mathrm{L}$ olan MLSS konsantrasyonunun $15300 \mathrm{mg} / \mathrm{L}$ değerine ulaştığını fakat KOİ giderim veriminin tüm çalışma periyodu boyunca \%40-60 aralığında elde edilebildiğini ortaya koymuştur. Reaktörün daha yüksek KOİ giderim verimi elde etmede bariz şekilde yetersiz kalması sızıntı suyunda mevcut bulunan hümik ve fulvik asit gibi bazı bileșiklerin zor parçalanabilirliğinin yanı sıra çamur yaşının yüksek olması ile ilişkilendirilmiştir. Sonuç olarak mikrobiyal topluluğun aktivitesinin kontrol edilmesi için uygun miktarda çamurun reaktörden atılarak uygun bir SRT değerinde işletim yapılması gerektiği önerilmiştir. Mevcut çalışmada flok yapısında meydana gelen değişimin, döngü sonlarında reaktörden çamur çekilmediği için oldukça yüksek SRT şartında ișletim yapılmasından ötürü granüler haldeki çamurun deflokülasyonundan ileri geldiği düşünülmüştür. Bu nedenle flok yapısının yeniden granüler hale gelmesi ve olası biyokütle kayıplarının önlenmesi amacıyla reaktör işletiminin 44. gününden itibaren sentetik atıksudaki başlangıç KOİ konsantrasyonu $250 \mathrm{mg} / \mathrm{L}$ değerinden $500 \mathrm{mg} / \mathrm{L}$ değerine artırılmıştır.

Reaktör işletiminde 44-52. günler arasında işletme şartlarının bozulmasına sebep olan ani $\mathrm{pH}$ düşüşünün, iki durumun çift etkisi nedeni ile ileri geldiği düşünülmüştür:

i. Başlangıç KOİ konsantrasyonunun artması sonucunda aerobik reaksiyonun son ürünü olan $\mathrm{CO}_{2}$ konsantrasyonunun, başlangıç KOİ konsantrasyonunun $250 \mathrm{mg} / \mathrm{L}$ olduğu şartlara göre daha fazla artması, 
Çizelge 5. Reaktör ișletiminin farklı așamalarında elde edilen ortalama değerler

\begin{tabular}{|c|c|c|c|c|c|c|c|}
\hline \multirow[b]{2}{*}{$\begin{array}{l}\text { Aşama } \\
\text { (Gün) }\end{array}$} & \multicolumn{7}{|c|}{ Ortalama değerler } \\
\hline & $\begin{array}{c}\text { MLSS } \\
(\mathrm{mg} / \mathrm{L})\end{array}$ & $\begin{array}{c}\text { AKM } \\
\text { (mg/L) }\end{array}$ & $\begin{array}{c}\mathrm{NH}_{4}{ }^{+} \\
(\mathrm{mg} / \mathrm{L})\end{array}$ & $\begin{array}{c}\mathrm{NH}_{4 \mathrm{~g}} \\
(\mathrm{mg} / \mathrm{L})\end{array}$ & $\begin{array}{c}\mathrm{NO}_{3}^{-} \\
(\mathrm{mg} / \mathrm{L})\end{array}$ & $\mathrm{NH}_{4 \mathrm{~g}} / \mathrm{NO}_{3}^{-}$ & $\begin{array}{c}\mathrm{PO}_{4}^{3-} \\
(\mathrm{mg} / \mathrm{L})\end{array}$ \\
\hline $0-15$ & 1758 & 51 & 0,49 & 11,5 & 10,3 & 1,18 & 14,5 \\
\hline $16-43$ & 2843 & 40 & 0,27 & 11,7 & 7,95 & 1,54 & 11,8 \\
\hline $44-52$ & 3003 & 99 & 4,46 & 19,6 & 7,87 & 2,51 & 18,5 \\
\hline
\end{tabular}

ii. Reaktörün $250 \mathrm{mg} / \mathrm{L}$ basslangıç KOİ konsantrasyonu şartlarında sahip olduğu alkalinitenin, $\mathrm{CO}_{2}$ konsantrasyonunun daha fazla artması durumunda yeteri kadar tamponlama kapasitesine sahip olmaması.

Elde edilen sonuçlar (Şekil 1-3) özet olarak değerlendirildiğinde reaktördeki işletme şartlarının bozulmasına yol açan $\mathrm{pH}$ düşüşünün meydana geldiği 44. güne kadar uygulanan işletme şartlarının yüksek KOİ giderme ve yüksek çökme performansına sahip olan çamurun uzun bekleme süreleri boyunca alıkonmasına imkan sağladığı tespit edilmiştir. Fakat reaktördeki $\mathrm{pH}$ değişiminin prosesi yöneten baskın mikroorganizma gruplarını değiştirerek 44. günden itibaren reaktör performansının bozulmasına yol açan önemli bir faktör olduğu söylenebilir. Bu nedenle reaktör işletiminde hem reaktörden belirli hacimde çamur atılmasının hem de döngü başlarında pH ayarlaması yapılmasının gerektiği olduğu sonucuna varılmıștır.

Farklı işletme koşullarının aktif çamurda aerobik granüllerin oluşumu üzerindeki etkisinin araştırıldığı çalışmada [19] HRT değerinin 8 ve 6,75 saat olarak ayarlandığı AKR'de denemeler gerçekleştirilmiştir. Elde edilen sonuçlara göre 17 hafta boyunca yürütülen 8 saatlik HRT ile yapılan işletimin biyokütlelerin granüler hale gelmesini sağlamak açısından yetersiz (süre bakımından uzun) kaldığı, bu süreçte işletmenin granülasyonu teşvik edebilecek olan yüzeysel gaz hızının artırılması ile kombine edilmesi hallerinde dahi HRT değerinin çamurun stabil hale gelmesine yardımcı olmadığı bildirilmiștir. Bu problemin HRT’nin 6,75 saate düşürülmesi ile çözülmesi sonucunda işletmenin farklı işletme koşulları ile kombine edilmesi sonucunda granüler biyokütlelerin stabilitesinin arttığı tespit edilmiştir. HRT değeri 8 saat iken yapılan işletmenin ilk birkaç gününde oldukça fazla sayıda filamentli mikroorganizma ve fungiden ibaret olan stabil olmayan ve parçalara ayrılabilen granül gelişimi gözlemlenmiștir. Bu süreçte çökme performansı düşük olan çamur, biyokütle yıkanması sonucunda sistemden uzaklaşmıştır. HRT değerinin 6,75 saate düşürülmesi ile yeni bir granülasyon süreci başlamıştır ve devam eden işletme süreci boyunca filament içermeyen kararlı (yüksek çökme performansına sahip olması nedeniyle biyokütle yıkanması oluşmayan) granüller yeniden oluşmaya başlamıştır.

HRT değerinin aerobik granüler çamur oluşumuna etkisinin incelendiği bir başka çalışmada [20] ise 3 ve 12 saatlik HRT değerlerine sahip iki özdeş reaktörün işletimi gerçekleștirilmiștir. Calışmadan elde edilen sonuçlarda 3 saatlik HRT şartında günlük 8 özdeş döngü ile işletilen reaktörde 16 döngülük işletme süresi sonunda ÇHİ değerinin $103 \mathrm{~mL} / \mathrm{g}$ değerinden $45 \mathrm{~mL} / \mathrm{g}$ değerine azaldığı tespit edilmiştir. Bu sonucun aksine 12 saatlik HRT şartında işletilen reaktörde ise 16 döngülük ișletme sonunda çamurun çökme performansının kötüleştiği, devam eden işletme sürecinde meydana gelen biyokütle yıkanması sonucunda MLSS konsantrasyonunun azaldığı, küçük granüllerin bu süreçte olușmaya başlaması ile çamurun çökme performansının ancak 22 gün sonunda iyileştiği tespit edilmiştir.

OYH'nin aerobik granüler çamur oluşumuna etkisinin incelendiği çalışmada [21] OYH değerleri 3, 6 ve $9 \mathrm{~kg}$ $\mathrm{KOI} / \mathrm{m}^{3}$.gün olacak şekilde başlangıç KOİ konsantrasyonları $1000 \mathrm{mg} / \mathrm{L}, 2000 \mathrm{mg} / \mathrm{L}$ ve 3000 mg/L olarak ayarlanan üç özdeș reaktörde deneyler yapılmıștır. Elde edilen sonuçlara göre OYH'nin belirli bir seviyeye kadar artması durumunda çamurun granüler özelliklerinin ve dolayısıyla reaktör performansının iyileştiği sonucu ortaya konmuştur. Söz konusu çalışmada en iyi reaktör performansı OYH’nin $6 \mathrm{~kg} \mathrm{KOİ} / \mathrm{m}^{3}$.gün olduğu reaktörde elde edilirken yükün artırılması KOİ gideriminde dalgalanmaya ve MLSS konsantrasyonunda azalmaya sebep olmuştur.

Başka bir çalışmada [22] farklı işletme şartlarının aerobik granüler çamur oluşumuna etkisini incelemek amacıyla dört farklı AKR'de deneyler gerçekleştirilmiştir. Her bir reaktörde, diğer üçü eşit ve biri farklı değerde olmak üzere OYH, çamur çöktürme süresi, aerobik döngü süresi ve hava debisi değişken faktör olarak denenmiştir. Elde edilen sonuçlara göre yüksek çökme performansına sahip aerobik granüler çamurun, başlangıç çamur çöktürme süresinin $15 \mathrm{dk}$. olduğu ve bu sürenin 45 günlük işletme süresi boyunca kademeli olarak 1 dk'ya kadar azaltıldığı reaktörde elde edildiği tespit edilmiştir. Sonuç olarak incelenen değișken faktörler arasında granüler çamur olușumuna etki eden en önemli faktörün çöktürme süresi olduğu bildirilmiştir.

AKR'ler için ana tasarım kriterinin floküler haldeki aktif çamur floklarının sistemden yıkanması halinde bu tip bir çamura nazaran daha yoğun ve dolayısıyla çökme hızı daha yüksek olan granüler haldeki çamurun elde edilmesine dayandığı bildirilmiştir [19]. Bu nedenle floküler biyokütlenin sistemden yıkanarak granüler çamur oluşumunun sağlanması amacıyla reaktör ișletiminin çökme aşamasında çamurun çöktürülmesi için ayrılan sürenin esas tasarım parametresi olduğu ve nispeten kısa çökme 
süresinin nihayetinde kısa sürede çökebilecek olan biyokütle partikülleri için seçicilik sağlayacağı belirtilmiştir. Mevcut çalışmanın alıştırma aşaması için yukarıda bahsedilen literatür çalışmalarında tespit edilen bulgular dikkate alınarak belirlenmiş olan işletme stratejisi, reaktördeki işletme şartlarının bozulduğu aşamaya kadar tüm işletme süresi boyunca çamurun MLSS konsantrasyonunun artmasına rağmen çok kısa bir sürede $(10 \mathrm{dk})$ çökmesi ve yüksek verimde KOİ giderimi sağlanması ile başarılı şekilde sonuçlanmıștır. Tüm deneysel çalışmalarda alıştırma aşamaları boyunca döngü sürelerinin kademeli olarak kısaltılması ile HRT değerinin azaltılmasının sağlanması ve her döngüde arıtılan sentetik atıksu hacminin artırılması ile hem HRT'nin azaltılması hem de OYH değerinin artırılmasının çift etkisi ile aktif çamurun çökme performansında tüm işletme süreleri boyunca iyileşme meydan gelmiştir. Öte yandan 15 günlük alıştırma aşaması boyunca çöktürme süresinin günlük olarak birer dakika kısalması da bu performansın artışına katkı sağlamıştır.

AKR sistemi kullanılarak yapılan benzer bir çalışmada [23] tüm işletme süresi boyunca MLVSS/MLSS oranı ortalama olarak \%87-88 tespit edilmiştir. Normal (sağlıklı) yapıda olan bir aktif çamur flokunun \%60-90 oranında MLVSS içerdiği belirtilmiştir [24]. Bu bakımdan MLVSS/MLSS oranı bir aktif çamur sisteminin işletilmesinde flokların organik madde içeriği bakımından durumunu ifade eden önemli bir kontrol parametresi olarak değerlendirilmektedir. Bu çalışmada MLVSS/MLSS oranı için elde edilen sonuçlar, tüm işletme süresi boyunca aktif çamur floklarının organik madde içeriği bakımından normal yapıda olduğunu ortaya koymuştur.

OYH'nin aerobik granüler çamur oluşumuna etkisinin araştırıldığı çalışmada [25] dört adet AKR işletimi gerçekleştirmiştir. Çalışmadan elde edilen sonuçlara göre reaktör performanlarının nispeten kötü olduğu daha düşük OYH şartında (1 ve $2 \mathrm{~kg} \mathrm{KOI} / \mathrm{m}^{3}$.gün) işletilen reaktörlerin $\mathrm{F} / \mathrm{M}$ oranının, OYH'nin daha yüksek (4 ve $8 \mathrm{~kg} \mathrm{KOI} / \mathrm{m}^{3}$.gün) olduğu diğer iki reaktörde elde edilen $\mathrm{F} / \mathrm{M}$ oranlarına kıyasla daha yüksek olduğu belirtilmiştir. Düşük performansa sahip olan reaktörlerde 52 günlük işletme süresi boyunca F/M oranları ortalama olarak 1,95 ve 2,94 kg KOİ/kg MLVSS.gün olarak hesaplanmıştır. Bu reaktörlerin arıtma performansı daha yüksek olan diğer reaktörlere kıyasla daha düşük MLVSS konsantrasyonuna sahip olduğu ve çamurun zayıf çökme özelliğine sahip olan biyokütlelerden ibaret olduğu belirtilmiştir. Performans bakımından daha yüksek arıtma verimine sahip reaktörde ise aerobik granüller ile 12. gün sonunda domine edilen biyokütleye sahip reaktörün $\mathrm{F} / \mathrm{M}$ oranının bu süre sonunda 1,35 kg KOİ/kg MLVSS.gün değerinden 0,33 $\mathrm{kg}$ KOİ/kg MLVSS.gün değerine azaldığı ve biyokütlenin 12000 mg/L MLVSS konsantrasyonuna ulaşarak stabilize hale geldiği tespit edilmiştir. OYH değerinin en yüksek olduğu arıtma performansı yüksek olan diğer reaktörde ise işletmenin 18. gününde granüler çamur oluşumu ile birlikte $\mathrm{F} / \mathrm{M}$ oranının 4,43 kg KOİ/kg MLVSS.gün değerinden 1,33 $\mathrm{kg}$ KOİ/kg MLVSS.gün değerine azaldığl, fakat bu değerin nihai olarak parçalara ayrılıp dağılarak reaktörden yıkanma ile uzaklaşacak olan genç biyokütleleri idare etme açısından yüksek olduğu açıklanmıştır. Sonuç olarak reaktör ortamındaki beslenme durumunun mikroorganizmaların kümelenmesini sağlamada önemli bir fizyolojik faktör olduğu ve yeterli düzeyde düşük $\mathrm{F} / \mathrm{M}$ oranlarının stabil aerobik granüllerin elde edilmesinde temel gereksinim olduğu belirtilmiştir. Söz konusu çalışmada en yüksek performansa ve arıtma verimine sahip olan reaktör için elde edilen F/M değerleri, mevcut çalışmada elde edilen $\mathrm{F} / \mathrm{M}$ değerleri ile uyumlu olmuştur.

\section{2. Çıkış suyu kalitesi}

Çıkış suyunun $\mathrm{NH}_{4}{ }^{+}$konsantrasyonunun tespit edilmesi için elde edilen sonuçlar (Şekil 5) reaktörde nitrifikasyon inhibisyonu sağlanmasına rağmen 44. güne kadar yapılan işletmede amonyumun yüksek verimde giderildiğini ve MLSS konsantrasyonunun işletme süresi boyunca nispi olarak artışı ile birlikte amonyumun mikroorganizmalar tarafından temel $\mathrm{N}$ kaynağı olarak kullanıldığını ortaya koymuştur.

Reaktör işletiminde 44-52. günler arasındaki ortalama $\mathrm{NO}_{3}{ }^{-}$konsantrasyonunun başlangıç $\mathrm{NH}_{4}{ }^{+}$ konsantrasyonunun artırılmasından önceki aşama için hesaplanan ortalama $\mathrm{NO}_{3}{ }^{-}$konsantrasyonundan düşük elde edilmesi;

i. 44. günden önceki aşamada reaktörde inhibisyon uygulanmasına rağmen nispeten düşük başlangıç $\mathrm{NH}_{4}^{+}$konsantrasyonu ile reaktöre sağlanan amonyumun mikroorganizmalar tarafindan temel $\mathrm{N}$ kaynağı olarak kullanılmasından ötürü inhibisyonun baskılandığını ve çıkış suyu $\mathrm{NH}_{4}{ }^{+}$konsantrasyonunun oldukça düşük seviyede elde edilmesine yol açtığını,

ii. 44. günden itibaren başlangıç $\mathrm{NH}_{4}{ }^{+}$ konsantrasyonu artmasına rağmen $\mathrm{NO}_{3}$ konsantrasyonunun artış göstermemesinin ve çıkış suyunda $\mathrm{NH}_{4}{ }^{+}$konsantrasyonunun artmasının inhibisyondan ileri geldiğini net şekilde ortaya koymuştur.

Atıksuların biyolojik arıtma sistemleri ile arıtılmasında mikroorganizma topluluğunu içeren aktif çamurun çökme performansı, hem organik maddeler bakımından arıtma performansını hem de arıtma çamurlarının bertarafı işlemlerinde çamurun yoğunlaştırma ve susuzlaştırma özelliklerini etkileyen önemli bir unsurdur. Çamurun çökme performansının yüksek olması ve mikroorganizmaların verimli şekilde çalışmalarının sağlanması ancak iyi derecede dizayn edilmiş ve kontrollü işletme şartları altında işletilen bir aktif çamur sisteminde mümkün olmaktadır. Doğası gereği 
birçok farklı işletme parametresi ile ilgilenmeyi ve üst düzeyde ișletme özeni sağlamayı gerektiren aktif çamur sistemleri üzerine araştırmalar yapılırken atıksu karakteristiklerinin iyi analiz edilmesi ve işletme parametrelerinin dikkatlice incelenmesi gerekmektedir. Bu çalışmada, çalışmanın amaçları doğrultusunda işletimi dizayn edilen AKR'nin işletiminde alıştırma aşaması süresince uygulanan işletme stratejileri, hem çok hızlı çökebilme özelliğine sahip olan hem de yüksek verimde KOİ giderme kabiliyetine sahip olan bir aktif çamurun kısa süreli bir alıștırma aşamasında nasıl elde edilebileceğini ortaya koymuştur.

Dünya genelinde özellikle yoğun şekilde yapılan tarımsal uygulamalarda kullanmak üzere yüksek miktarda tüketimi ve bu oranda üretimi yapılarak rezervleri tüketilen $\mathrm{P}$ ve gübre üretimi için yüksek enerji gerektiren $\mathrm{N}$ gibi kaynakların sürdürülebilir şekilde kullanımını sağlamak için son yıllarda yapılan çalıșmalar arasında atıksu arıtma tesislerinde nütrient geri kazanımı konusu oldukça yoğun ilgi görmektedir. $\mathrm{Bu}$ çalışmadan elde edilen sonuçlara göre $\mathrm{N}$ ve $\mathrm{P}$ gideriminin yapılmadığ veya kısmen sağlandığı temel olarak karbon giderimi üzerine dizayn edilmiş klasik aktif çamur tesislerinin çıkış sularından nütrient geri kazanım potansiyelini artırmak üzere nitrifikasyon inhibisyonunun alternatif bir yaklaşım olarak potansiyelinin bulunduğu tespit edilmiştir. Bu potansiyeli daha fazla artırmak üzere ileride yapılabilecek çalışmalarda reaktör işletiminin daha uzun süreli yapılması, farklı inhibitör maddeler ile çalışılarak nitrifikasyon inhibisyonunun veriminin artırılması ve farklı substrat kaynaklarının ve işletim parametrelerinin değişiminin çıkış suyu kalitesi üzerine olan etkisinin araştırılması önerilmektedir.

\section{Teşekkür}

$\mathrm{Bu}$ çalışmayı FYL-2018-6718 numaralı proje ile destekleyen Süleyman Demirel Üniversitesi Bilimsel Araştırma Projeleri Birimine teşekkür ederiz.

\section{Kaynakça}

[1] Tornroth-Horsefield, S., Neutze, R. 2008. Opening and Closing the Metabolite Gate. Proceedings of the National Academy of Sciences U.S.A, 105(50):19565-6.

[2] Sengupta, S., Nawaz, T., Beaudry, J. 2015. Nitrogen and Phosphorus Recovery from Wastewater. Current Pollution Reports, 1, 155166.

[3] Manav, N. 2006. Ardışık kesikli reaktör ile evsel atıksulardan azot ve fosfor giderimi. Yıldız Teknik Üniversitesi Fen Bilimleri Enstitüsü, Yüksek Lisans Tezi, 85s, İstanbul.

[4] Oleszkiewicz, J., Kruk, D., Devlin, T., Lashkarizadeh, M., Yuan, Q. 2015. Options for
Improved Nutrient Removal and Recovery from Municipal Wastewater in the Canadian Context. http://cwn-rce.ca/wpcontent/uploads/2016/04/Oleszkiewicz-KIReport-March-2015.pdf (Erişim Tarihi: 18.10.2019).

[5] Hamilton, R., Braun, B., Dare, R., Koopman, B., Svoronos, S. A. 2006. Control Issues and Challenges in Wastewater Treatment Plants. IEEE Control Systems Magazine, 26(4), 63-69.

[6] Türkiye İstatistik Kurumu Belediye Atıksu İstatistikleri.

https://biruni.tuik.gov.tr/medas/?kn=120\&loca $\underline{\text { le}=\operatorname{tr}}$ (Erişim Tarihi: 28.11.2019).

[7] Anonim, 2004. Su Kirliliği Kontrolü Yönetmeliği. Resmi Gazete, No: 25687.

[8] Anonim, 2008. Su Kirliliği Kontrolü Yönetmeliği. Resmi Gazete, No: 26786.

[9] Anonim, 2016. Su Kirliliği Kontrolü Yönetmeliğinde Değişiklik Yapılması Hakkında Yönetmelik. Resmi Gazete, No: 29589.

[10] Anonim, 2006. Kentsel Atıksu Arıtımı Yönetmeliği. Resmi Gazete, No: 26047.

[11] Pastor, L., Marti, N., Bouzas, A., Seco., A. 2008. Sewage Sludge Management for Phosphorus Recovery as Struvite in EBPR Wastewater Treatment Plants. Bioresource Technology, 99, 4817-4824.

[12] Howorth, C., Wirtel, S. 2015. Nutrient Recovery Delivers Economic and Environmental Sustainability, and Helps You Meet Effluent and Biosolids Nutrient Permits. https://cdn.ymaws.com/www.ncsafewater.org/ resource/collection/DA8375FB-1514-43259CF60369B08C4385/WW_Mon NO0N 12.45 Howort h_PAPER.pdf (Erişim Tarihi: 04.11.2019).

[13] Jeyanayagam, S., Hahn, T., Fergen, R., Boltz, J. 2012. Nutrient Recovery, an Emerging Component of a Sustainable Biosolids Management Program. Proceedings of the Water Environment Federation, 2012(2), 1078-1088.

[14] Lu, H., Oehmen, A., Virdis, B., Keller, J., Yuan, Z. 2006. Obtaining Highly Enriched Cultures of Candidatus Accumulibacter Phosphates Through Alternating Carbon Sources. Water Research, 40, 3838-3848.

[15] Tatari, K., Gülay A., Thamdrup, B., Albrechtsen, H. J., Smets, B. F. 2017. Challenges in Using Allylthiourea and Chlorate as Specific Nitrification İnhibitors. Chemosphere, 182, 301305.

[16] APHA (American Public Health Association), 1999. Standard Methods for the Examination of Water and Wastewater. 20th edition. American 
Public Health Association. Washington, DC, USA, 874s.

[17] Jadhao, R. K., Dawanse, S. D. 2013. Effect of Hydraulic Retention Time and Sludge Retention Time on Membrane Bioreactor: Performance in Summer Season. International Journal of Chemical and Physical Sciences, 2(2), 1-8.

[18] Tsilogeorgis, J., Zouboulis, A., Samaras, P., Zamboulis, D. 2008. Application of a Membrane Sequencing Batch Reactor for Landfill Leachate Treatment. Desalination, 221(1-3), 483-493.

[19] Beun, J.J., Hendriks, A., van Loosdrecht, M. C. M., Morgenroth, E., Wilderer, P. A., Heijnen, J. J. 1999. Aerobic Granulation in a Sequencing Batch Reactor. Water Research, 33(10), 2283-2290.

[20] Wang, F., Yang, F. L., Zhang, X. W., Liu, Y. H., Zhang, H. M., Zhou, J. 2005. Effects of Cycle Time on Properties of Aerobic Granules in Sequencing Batch Airlift Reactors. World Journal of Microbiology and Biotechnology, 21(8-9), 13791384.

[21] Bindhu, B. K., Madhu, G. 2013. Influence of Organic Loading Rates on Aerobic Granulation Process for The Treatment of Wastewater.
Journal of Clean Energy Technologies, 1(2), 8487.

[22] Gao, D., Liu, L., Wu, W. M. 2011. Comparison of Four Enhancement Strategies for Aerobic Granulation in Sequencing Batch Reactors. Journal of Hazardous Materials, 186(1), 320327.

[23] Hajiabadi, H., Moghaddam, M. R. A., Hashemi, S. H. 2009. Effect of Sludge Retention Time on Treating High Load Synthetic Wastewater Using Aerobic Sequencing Batch Reactors. Iranian Journal of Environmental Health Science and Engineering, 6(4), 217-222.

[24] Jenkins, D., Richard, M. G., Daigger, M. T. 2004. Manual on the Causes and Control of Activated Sludge Bulking, Foaming, and Other Solid Separation Problems. 3rd edition. CRC Press, Taylor and Francis Group. Florida, Amerika Birleșik Devletleri. 177s.

[25] Tay, J. H., Pan, S., He, Y., Tay, S. T. L. 2004. Effect of Organic Loading Rate on Aerobic Granulation. I: Reactor Performance. Journal of Environmental Engineering, 130(10), 10941101. 